\title{
Biodegradation Potentials of Bacterial Isolates from Auto- Mechanic Workshops in Oluku, Edo State, Nigeria
}

\author{
Oshoma C.E. ${ }^{1}$, Eze E.E. ${ }^{1}$, Omonigho S. E. ${ }^{1, *}$ \\ ${ }^{1}$ Department of Microbiology, University of Benin, Benin City, Nigeria \\ *esharegoma.omonigho@uniben.edu
}

\begin{abstract}
The frequent discharge of used petroleum products from automobiles has become a major source of concern due to unguided discharge into the soil environment, hence the need for biodegradation of the products. Bacterial species were isolated from contaminated soil in mechanic workshops and screened for their for hydrocarbon degradation potentials using standard microbiological procedures. Physicochemical properties of the contaminated soil were also analysed using standard techniques. The highest and lowest heterotrophic bacterial counts of $2.82 \pm 0.16 \times 10^{8}$ and $2.09 \pm$ $0.32 \times 10^{8} \mathrm{cfu} / \mathrm{g}$ were from the control soil and site 1 respectively. For hydrocarbon utilizing bacterial, Site 2 had the highest load of $8.33 \pm 2.55 \times 10^{5}$ while the control had the least $1.35 \pm 0.33 \times$ $10^{4} \mathrm{cfu} / \mathrm{g}$. The bacterial isolates from the contaminated soil were found to be Corynebacterium kutsceri, Escherichia coli, Bacillus licheniformis, Bacillus subtilis, Bacillus megaterium, Klebsiella oxytoca, Staphylococcus aureus, Pseudomonas aeruginosa and Micrococcus luteus. The highest and lowest in the frequency of occurrence among the isolates were B. subtilis $(27.5 \%)$ and E. coli (1.4\%) respectively. The screened hydrocarbon utilizing bacterial isolates were $C$. kutseri, $B$. subtilis and $P$. aeruginosa. The ability to degrade crude oil revealed that bacterial consortium had the highest growth profile of $12.90 \times 10^{5}$ while the least was $C$. kutsceri with values of $8.20 \times 10^{5} \mathrm{cfu} / \mathrm{g}$. The consortium bacteria had the highest percentage of hydrocarbon products degradation. The ability of the consortium bacteria to remove a high percentage of crude oil components makes it potentially useful for bioremediation of site highly contaminated with petroleum hydrocarbon.
\end{abstract}

Keywords: Bacteria, crude oil, mechanic workshops and contaminated soil

\subsection{Introduction}

With an over increasing world population, petroleum products are extensively used all over the globe that apparently have strong connection to environmental pollution due to hydrocarbon discharge (Bidoia et al., 2010). Petroleum spillage occurs from several causes such as, leakages from pipelines and storage tanks, waste disposal, blowout, accidental spills through transportation and uses (Obayori et al., 2014). Environmental pollution by petroleum products remain an unavoidable consequence of oil exploitation, transportation and distribution activities. Petroleum and its products toxicity on contaminated soil, depends on their concentration, composition, environmental factors and biological state of the organisms at the time of contamination (Eze et al., 2014).

The Nigerian environment is known for indiscriminate, nonchalant and highly unregulated petroleum products disposal (Odjegba and Sadiq, 2000), causing a decline in soil quality. Mechanic workshop often dispose-off used oil into open grounds, from where it finds its way into canals, drainages and underground water (Obayori et al., 2014). It may be of interest to note that small amount of petroleum hydrocarbon released into aquifers could results to concentrations of dissolved hydrocarbons which exceed regulatory limits (Spence et al., 2005). Also, exposure of petroleum hydrocarbons for a long time can cause liver or kidney disease, damage to bone marrow and high risk of cancer (Lloyd and Cackette, 2001). To overcome the environmental risk associated with petroleum and its products, research is now geared toward remediating the contaminated soil. 
Indiscriminate discharge of used petroleum products from vehicles is a source of pollution in mechanic workshops and its environs. Hence, the need for a concerted effort in studying the feasibility of using oil degrading bacteria for remediation. Okon (2006) advocated for biological remediation of petroleum contaminated soil due to the negative consequences of physicochemical approaches. Bioremediation of petroleum by natural population of microorganisms is one of the effective mechanisms of reclaiming soil and aquifers. The clean-up of hydrocarbon by this approach is very attractive because it is easy to maintain, applicable over a large area, cost effective and destruction of the contaminant (Bento et al., 2005). A wide range of bacteria and fungi have been implicated to exhibit the ability to degrade or utilize hydrocarbon as substrates (Challian et al., 2004; Ekhaise and Nkwelle, 2011).

Mechanic workshops used various petroleum products such as engine oil, diesel and kerosene on daily bases. The disposal of these products results in hardening or change in the texture of the soil, which has an effect on the microbiological and physicochemical quality of the contaminated soil. Hence, in view of the high number of mechanic workshops and their unguided disposal of used petroleum products into the environment, there lies the need to ameliorate the environmental risk associated with these products. Therefore, this investigation aims at assessing the potential of hydrocarbon degrading bacterial isolates from contaminated soil in mechanic workshops.

\subsection{Materials and Methods}

\subsection{Study Area and Soil Sample Collection}

The study areas were two auto mechanic workshops located at Site 1 and Site 2 within Ovia North East Local Government area, Edo State. Soil samples within these areas were collected into sterile polyethene bags using a soil auger at a depth of $0-15 \mathrm{~cm}$. The samples were immediately transported to the laboratory for microbiological and physicochemical analysis.

\subsection{Isolation and Enumeration of Bacteria}

A 10 grams of contaminated soil sample was suspended in $90 \mathrm{ml}$ of sterile distilled water in a conical flask. The soil suspension was thoroughly mixed and 10 fold serial dilution was carried out. Using pour plate technique, $0.1 \mathrm{ml}$ from the dilutions were plated in duplicates on sterile Nutrient agar (NA), amended with Nystatin to discourage fungi growth, for total heterotrophic bacterial counts. The NA plates were incubated aerobically at $37^{\circ} \mathrm{C}$ for $24-48 \mathrm{~h}$. The number of viable cells in the samples were calculated from the colonies formed, inoculum size and dilution factor, then expressed as colony forming unit per gram (Cain et al., 2013).

\subsection{Enumeration, Characterization and Identification of Hydrocarbon Utilizing Bacteria (HUB)}

This involved cultivation of hydrocarbon degraders in minimal salt medium (with crude oil as carbon source). Minimal salt medium was prepared according to the composition formulated by Mills et al. (1978) as modified by Okpokwasili and Okorie (1988). One gram (1.0 g) of the oil contaminated soil sample was dissolved in test tubes containing $9 \mathrm{ml}$ of sterile MSM and serially diluted (10-fold) using MSM as diluent. An aliquot $(0.1 \mathrm{ml})$ of the dilutions was plated out in duplicate under aseptic condition using pour plate technique in the modified minimal salt agar (MSA) with $1 \%$ crude oil as carbon source, incorporated with $0.5 \mathrm{ml}$ Nystatin solution. The plates were incubated at $37^{\circ} \mathrm{C}$ for 5 days.

After incubation, HUBs were enumerated, colonies of bacteria grown on the agar plates were counted, isolated, purified by streaking on NA plates and stored on NA slants for cultural characterization and identification. The bacterial isolates were characterised and identified on the basis of taxonomic schemes published in Bergey's manual of Determinative Bacteriology (Holt et al., 1994). Bacterial isolates were characterised on the basis of their cultural, morphological and biochemical characteristics. The identified isolates were maintained on NA slants at $4{ }^{\circ} \mathrm{C}$ for further studies. 


\subsection{Screening of Isolated Bacterial for Utilization of Hydrocarbon}

Degradation potential of HUB was screened according to the modified method of Hanson et al. (1993); Bidoia et al. (2010) using 2,6- dichlorophenol indophenol (DCPIP) as redox indicator. Minimal salt medium (MSM) $(100 \mathrm{ml})$ was transferred into $250 \mathrm{~mL}$ Erlenmeyer flasks and sterilized at $121{ }^{\circ} \mathrm{C}$ for $15 \mathrm{~min}$. After cooling, $1 \%$ of blended crude oil, filter sterilized, was added and $0.55 \mathrm{w} / \mathrm{v}$ DCPIP as redox indicator. The bacterial isolates of $1 \mathrm{ml}$ was inoculated, incubated at $28 \pm 2{ }^{\circ} \mathrm{C}$ for $144 \mathrm{~h}$ on a Gyrator Shaker at a speed of $180 \mathrm{rpm}$. One of the flask was uninoculated and served as the control. The flasks were monitored daily for colour change (from deep blue to colourless). Absorbance of all the assays was measured using UV visible Spectrophotometer (model 752), at an optical density of 600nm, to test for degradation ability of the isolates.

\subsection{Biodegradation Potentials of Screened Isolation}

The bacterial isolates which had scored the most reduced optical density during the screening test were used for degradation of crude oil. Time-course degradation of the crude oil was carried out in MSM according to the method of Mills et al. (1978) as modified by Okpokwasili and Okorie (1988). The medium was supplemented with $1 \%$ crude oil and inoculated with overnight culture of isolates according to Ekhaise and Nkwelle (2011) method. All the flasks were incubated at $28 \pm 2{ }^{\circ} \mathrm{C}$ in a Gyratory shaker at $150 \mathrm{rpm}$ and monitored for a period of 15 days. The bacterial growth was monitored using pour plate technique on a nutrient agar plates. After incubation period, residual oil components concentrations were determined by Gas chromatography.

\subsection{Physicochemical Parameter Determination of Soil Samples}

Several physical and chemical properties of soil samples were evaluated. Soil sample pH was determined in 1:1 soil/water suspension ratio using pH meter (Jenway 3051) as described by Cowan and Steel (2004). The conductivity and sulphate content were determined according to the method of Onojake and Osuji (2012). Available phosphorous, nitrogen, exchangeable cations $\left(\mathrm{Na}^{+} . \mathrm{Ka}^{+} . \mathrm{Ca}^{2+}\right.$ and $\mathrm{Mg}^{2+}$ ) and total hydrocarbon content (THC) were determined using the procedures stated by Akpoveta et al. (2011). The chloride content was determined using titrimetric procedure while total organic carbon (TOC) was by chronic acid titrimetric method of Eze et al. (2014). Heavy metal contents $\mathrm{Fe}^{2+}, \mathrm{Mn}^{2+}$, $\mathrm{Pb}^{2+}, \mathrm{Zn}^{2+}$ and $\mathrm{Ni}^{2+}$ ) were analysed by atomic absorption spectrophotometer (Alpha 4 AAS) after digestion of sample with nitric acid and distill water.

\subsection{Results and Discussion}

Degradation of petroleum components by microorganisms is possible due to the presence of enzymes secreted by them. The complex hydrocarbons can be degraded by those microorganisms which possess high enzymatic activities (Alexander, 1994). The heterotrophic bacterial (THB) counts showed that the soil (both contaminated and uncontaminated) contained bacteria. The highest and lowest bacterial load of $2.82 \pm 0.16 \times 10^{8}$ and $2.09 \pm 0.32 \times 10^{8} \mathrm{cfu} / \mathrm{g}$ was observed in the control and site 1 respectively. For the case of the hydrocarbon utilizing bacterial (HUB), site 2 had the highest load of $8.33 \pm 2.55 \times 10^{5}$ while the control site had the lowest load of $1.35 \pm 0.33 \times 10^{4} \mathrm{cfu} / \mathrm{g}$ (as seen in Table 1). Higher bacterial counts were observed in uncontaminated soil than the auto-mechanic workshop soil contaminated with petroleum products. Possible reason could be due to non-exposure of soil to petroleum products which did not distort the physicochemical and biological properties of this soil. The low bacterial counts in the mechanic workshops may be due to inability of some organisms to tolerate high concentration of the petroleum products in these environments. Same effect was observed in the report of Stephen et al. (2013).

The increase in HUB count from the mechanic workshop soil than the uncontaminated soil could be that these organisms have developed resistance effect against the hydrocarbon products found in the soil. It could also be a reflection of the soil microflora ability to strive and proliferate in these environments, despite the deliberate exposure of soil to varying dose of petroleum products (Selvakumar et al., 2014). The bacterial isolates from the contaminated soil were found to be 
Corynebacterium kutsceri, Escherichia coli, Bacillus licheniformis, Bacillus subtilis, Bacillus megaterium, Klebsiella oxytoca, Staphylococcus aureus, Pseudomonas aeruginosa and Micrococcus luteus as shown in Table 2. The highest in the frequency of occurrence among the isolates was B. subtilis $(27.5 \%)$ while E. coli had the lowest percentage occurrence of $1.4 \%$. The identified bacterial isolates have also been reported by various authors as the most predorminant hydrocarbon degrading bacterial (Rahman et al., 2002; Selvakumar et al., 2014; Mbachu et al 2014). These bacterial identified had wide spread in the soil and can easily degrade hydrocarbon. The dominance of B. subtilis on the crude oil polluted soil may be due to the ability to produce spores which may shield them from the toxic effect of the hydrocarbon.

Table 1: Total Heterotrophic Bacterial (THB) and Hydrocarbon Utilizing Bacterial (HUB) Counts of Soil Samples Collected

\begin{tabular}{lll}
\hline Area & THB $\left(\times \mathbf{1 0}^{\mathbf{8}} \mathbf{c f u} / \mathbf{g}\right)$ & HUB $(\mathbf{c f u} / \mathbf{g})$ \\
\hline Site 1 & $2.09 \pm 0.32$ & $4.07 \pm 1.10 \times 10^{5}$ \\
Site 2 & $2.33 \pm 0.48$ & $8.33 \pm 2.55 \times 10^{5}$ \\
Control & $2.82 \pm 0.16$ & $1.35 \pm 0.33 \times 10^{4}$ \\
\hline
\end{tabular}

Table 2: Frequency of Occurrence (\%) of HUB Isolates from the Soil Samples Collected from Mechanic Workshop

\begin{tabular}{lc}
\hline Bacterial Isolates & \% frequency \\
\hline Corynebacterium kutsceri & 7.2 \\
Escherichia coli & 1.4 \\
Bacillus licheniformis & 17.4 \\
Bacillus subtilis & 27.5 \\
Bacillus megaterium & 11.6 \\
Klebsiella oxytoca & 10.1 \\
Staphylococcus aureus & 4.3 \\
Pseudomonas aeruginosa & 13.0 \\
Micrococcus luteus & 7.2 \\
\hline
\end{tabular}

Redox indicator is a common means of measuring hydrocarbon utilizing bacteria in a contaminated environment (Bidoia et al., 2010). Screening of bacteria capable of utilizing crude oil as a sole carbon source is by the use of DCPIP. This a rapid and low cost procedure (Selvakumar et al., 2014). The ability of bacteria to utilize crude oil was ascertain by mainly colour change observation of DCPIP, where we have the quantified decolouration time indicating the best strain for crude oil degradation (Bidoia et al., 2014). The ability of bacterial isolates to utilize crude oil was screened as shown in Table 3. The isolates that decolourized DCPIP in the shortest time were used for the growth profile test. The isolates were found to C. kutseri, B. subtilis and P. aeruginosa with an OD values of 0.207, 0.140 and 0.187 respectively. All the bacterial isolates had the ability to grow on crude oil as their sole carbon source and energy when screened for crude oil utilization. Amazingly, same genera of bacterial have been implicated in hydrocarbon utilization, mostly Bacillus and Pseudomonas spp, by many authors (Oboh et al., 2010; Selvakumar et al., 2014; Sebiomo et al., 2011; Ekhaise and Nkwelle, 2011). 
Table 3: Screening of Bacterial Isolates for Crude Oil Utilization Potentials

\begin{tabular}{lll}
\hline Bacterial Isolates & Observed Colour Change & OD at 600 nm \\
\hline Corynebacterium kutsceri & Colourless after $96 \mathrm{~h}$ & 0.207 \\
Escherichia coli & Blue after $144 \mathrm{~h}$ & 0.348 \\
Bacillus licheniformis & Colourless after $120 \mathrm{~h}$ & 0.212 \\
Bacillus subtilis & Colourless after $48 \mathrm{~h}$ & 0.140 \\
Bacillus megaterium & Colourless after $96 \mathrm{~h}$ & 0.280 \\
Klebsiella oxytoca & Colourless after $96 \mathrm{~h}$ & 0.220 \\
Staphylococcus aureus & Colourless after $120 \mathrm{~h}$ & 0.290 \\
Pseudomonas aeruginosa & Colourless after $48 \mathrm{~h}$ & 0.187 \\
Micrococcus luteus & Light blue after $144 \mathrm{~h}$ & 0.513 \\
\hline
\end{tabular}

Figure 1 shows growth profile of the bacterial isolates screened during the utilization of crude oil. Increase in growth over a period of 15 days showed the bacteria to utilize hydrocarbon as their sole carbon source. However, the highest growth profile on day 15 was found to be the consortium of the three bacteria, next was $B$. subtilis while the least was $C$. kutsceri with values of $12.90 \times 10^{5}, 8.20 \times 10^{5}$ and $7.60 \times 10^{5} \mathrm{cfu} / \mathrm{g}$ respectively. Eze et al. (2014) reported that soil environments contaminated with hydrocarbon are likely to contain microbial populations of diverse taxonomic characteristics capable of degrading the pollutant. Degradation of macromolecules in the contaminant to smaller molecules is influenced by range of useful enzymes expressed by the microorganisms that help in breaking down or decomposition of contaminant. The growth profile revealed no distinct lag phases exhibited by the bacterial isolates and their consortium. The increase in bacterial population of the crude oil degraders could be due to the fact that there is available nutrient supplied by the oil for their growth (Akpoveta $e t$ al., 2011). The crude oil served as sole carbon and energy sources to the bacteria.

The percentage removal of hydrocarbon components by the bacterial isolates is shown in Figure 2. The consortium of the three bacteria had the highest percentage hydrocarbon removal and the least was $C$. kutsceri with value 89.67 and $57.25 \%$ respectively. The utilization of hydrocarbon help the organism to increase in cell number with a concomitant decrease in hydrocarbon concentration during the incubation period (Sebiomo et al., 2011). This observation agreed with the work of Sebiomo et al. (2011) that the ability of microorganisms to grow in crude oil indicate effective hydrocarbon degradation potential. Worthy of note is that all the bacterial isolates were resident of the polluted environment hence, their biodegradation ability to the contaminants. For a complete removal of pollutant, biodegradation has been proven to be the best form. This potential should be improve in order to develop a faster means of clean-up of contaminated soil. The success of remediating polluted environment depends on microorganisms in close physical contact with the crude oil degrade. Therefore, to optimize biodegradation rate is to improve the growth rate of microflora that are indigenous to the soil. On a final analysis, the best way for successful removal/clean-up of pollutant is to increase the rate of biodegradation potentials of indigenous bacteria found in the contaminated soil. Based on the crude oil utilization capacity, the consortium is the most active degrader in the oil. This is suggestive of a synergistic relationship among individual members of the consortium that might have invariably boosted the degradative potential of the bacterial consortium (Ghazali et al., 2004).

Hydrocarbon degrading bacteria have been shown to attack more on the aliphatic and light aromatic fraction of the crude oil (Okerentugba and Ezeronya, 2003), hence the percentage increase in the removal of these products from the oil. The consortium had the highest percentage removal of various fractions of crude oil analysed followed by $B$. subtilis after 15 day of incubation. This agreed with the findings of Mbachu et al. (2014) who reported that B. subtilis exhibited the highest degradation potential $(66.7 \%)$ on used engine oil. The result of this investigation is in line with the theory that individual member in a microbial community performs significant roles and also depend on the presence of different species and strains to effectively degrade crude oil in the environment (Ghazali et al., 2004). While in this study, high percentage crude oil components were removed by the microorganisms, 
insignificant value of $3 \%$ of the crude oil components was removed from the control medium. This could be influenced by physical factors such as run-off, flood and leaching, evaporation and photooxidation (Malik and Ahmed, 2011).

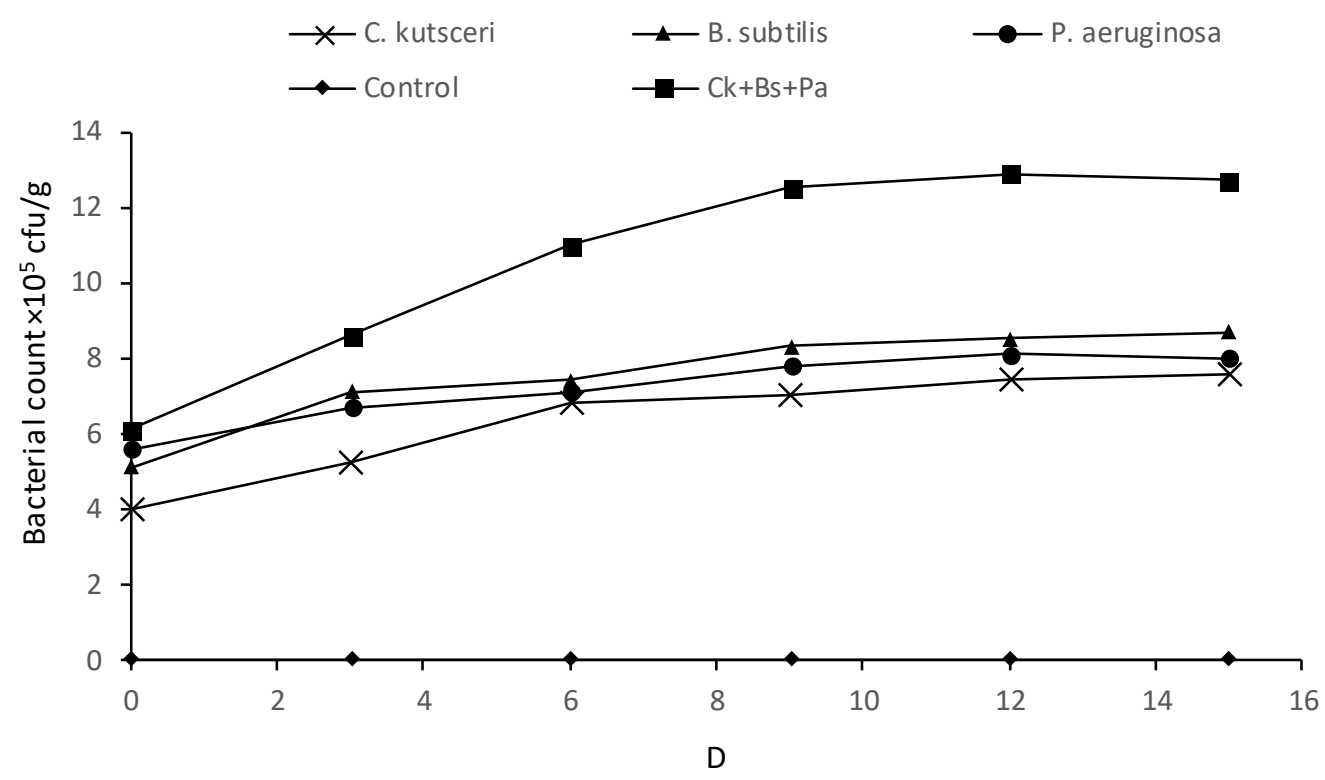

Figure 1: Total bacterial growth profile of the screened isolated and its consortium during the degradation of $1 \%$ crude oil.

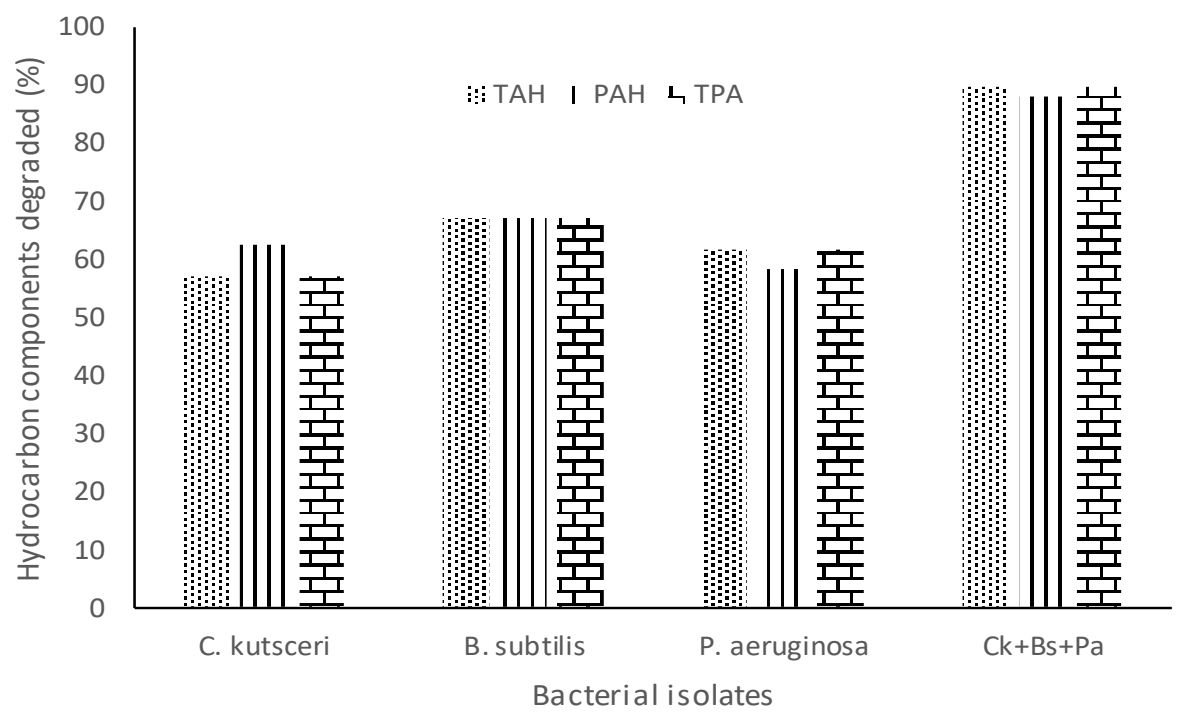

Figure 2: Percentage removal of $1 \%$ crude oil components by bacterial isolates and its consortium after 15 days incubation. TAH, Total aliphatic hydrocarbon; PAH, Polycyclic aromatic hydrocarbon and $\mathrm{TPH}$; Total petroleum hydrocarbon

The physicochemical properties of the soil samples showed varying values of the parameters analysed. The physicochemical parameters conducted on the oil polluted soil and oil free soil samples are shown in Table 4. The $\mathrm{pH}$ of the contaminated soil site 1 was more acidic than site 2 and control with values $6.143,6.233$ and 7.160 respectively. However, there was no statistical difference in $\mathrm{pH}(\mathrm{p}>0.05)$. The polluted sites had the highest electric conductivity, heavy metals and total organic carbon than the 
control soil. $\mathrm{pH}$ of the contaminated soil was found to be acidic. The low $\mathrm{pH}$ may be due to increased degradation of crude oil by the organisms in the soil, resulting in accumulation of acidic metabolites (Ijah and Abioye, 2003). Phosphorus and sulphate were higher in the contaminated than the control soil. Phosphorus availability for microorganisms in the soil may be restricted by its tendency to precipitate in the presence of certain metals such as $\mathrm{Ca}^{2+}, \mathrm{Mg}^{2+}$ and $\mathrm{Fe}^{2+}$. Increase in sulphate content can be attributed to the fact that there is continual replacement after being removed from soil (Eze et al., 2014). Nitrogen is an essential component of protein and nucleic acid. In most living being, nitrogen is taken up as assimilable nitrogen. Nitrogen can be lost from soil because some species of bacteria convert nitrate to gaseous nitrogen by using nitrate as a metabolic electron acceptor in place of oxygen (Nester et al., 2001). There was high level of electric conductivity in the polluted soils than the control soil, probably due to the presence of ions from the hydrocarbon introduced into the soil (Onojake and Osuyi, 2012). The high total organic carbon of the contaminated soil may be as a result of continuous released of the product into the soil. Same effect was found for THC, this could be a direct consequence of the unregulated discharged of petroleum products to the receiving soil.

Table 4: Physicochemical Properties of the Soil Samples

\begin{tabular}{llll}
\hline Parameter & Control & Site 1 & Site 2 \\
\hline $\mathrm{pH}$ & $7.160 \pm 0.071$ & $6.143 \pm 0.203$ & $6.233 \pm 0.493$ \\
Electric conductivity (uS/cm) & $28.667 \pm 2.136$ & $84.400 \pm 9.322$ & $81.800 \pm 10.652$ \\
Total organic carbon $(\%)$ & $1.277 \pm 0.177$ & $3.047 \pm 0.307$ & $2.733 \pm 0.421$ \\
Phosphorus $(\mathrm{mg} / \mathrm{kg})$ & $1.953 \pm 0.189$ & $3.483 \pm 0.142$ & $5.303 \pm 0.273$ \\
Total nitrogen $(\mathrm{mg} / \mathrm{kg})$ & $0.677 \pm 0.015$ & $0.057 \pm 0.009$ & $0.040 \pm 0.006$ \\
Total hydrocarbon content $(\mathrm{mg} / \mathrm{kg})$ & $55.127 \pm 1.213$ & $202.530 \pm 3.514$ & $286.170 \pm 2.892$ \\
Sulphate $(\mathrm{mg} / \mathrm{kg})$ & $0.180 \pm 0.46$ & $0.323 \pm 0.035$ & $0.817 \pm 0.084$ \\
$\mathrm{Cation}$ exchange capacity $(\mathrm{mg} / \mathrm{kg})$ & $2.686 \pm 0.283$ & $7.569 \pm 1.179$ & $5.103 \pm 0.076$ \\
$\mathrm{Fe}^{2+},(\mathrm{mg} / \mathrm{kg})$ & $0.275 \pm 0.157$ & $10.750 \pm 0.947$ & $8.677 \pm 0.667$ \\
$\mathrm{Mn}^{2+}(\mathrm{mg} / \mathrm{kg})$ & $0.078 \pm 0.003$ & $3.093 \pm 0.321$ & $1.464 \pm 0.154$ \\
$\mathrm{~Pb}^{2+},(\mathrm{mg} / \mathrm{kg})$ & $0.150 \pm 0.057$ & $0.647 \pm 0.0$ & $0.620 \pm 0.113$ \\
$\mathrm{Zn}{ }^{2+}(\mathrm{mg} / \mathrm{kg})$ & $0.077 \pm 0.019$ & $0.763 \pm 0.093$ & $0.437 \pm 0.047$ \\
$\mathrm{Ni}{ }^{2+},(\mathrm{mg} / \mathrm{kg})$ & 0 & $0.653 \pm 0.101$ & $0.350 \pm 0.012$ \\
$\mathrm{Cl},(\mathrm{mg} / \mathrm{kg})$ & $2.313 \pm 0.193$ & $7.787 \pm 0.300$ & $8.100 \pm 1.489$ \\
$\mathrm{Sand} \%$ & $85.157 \pm 2.079$ & $73.763 \pm 2.509$ & $76.737 \pm 2.039$ \\
$\mathrm{Clay} \%$ & $12.657 \pm 0.315$ & $23.070 \pm 2.577$ & $19.923 \pm 1.390$ \\
Silt \% & $1.753 \pm 0.122$ & $3.167 \pm 0.549$ & $3.340 \pm 0.655$ \\
$\mathrm{Moisture} \mathrm{content}(\%)$ & $7.893 \pm 1.036$ & $14.267 \pm 1.943$ & $17.633 \pm 2.898$ \\
Bulk density $\left(\mathrm{g} / \mathrm{cm}^{3}\right)$ & $0.730 \pm 0.026$ & $0.903 \pm 0.003$ & $0.973 \pm 0.012$ \\
\hline
\end{tabular}

\section{References}

Akpoveta, O. V., Egharevba, F., Medjor, O. W., Osaro, K. I. and Enyemike, E. D., (2011). Microbial Degradation and its Kinetics on Crude Oil Polluted Soil. Research Journal of Chemical Sciences, 1(6), pp. 8 -14.

Alexander, M., (1994). Biodegradation and bioremediation. Academic press, New York.

Bento, F.M., Camargo, F.A.O., Okeke, B.C. and Frankenberger, W.T., (2005). Comparative bioremediation of soils contaminated with diesel oil by natural attenuation, biostimulation and bioaugmentation. Bioresource Technology, 96, pp.1049 - 1055.

Bidoia, E.D., Montagnolli, R. N. and Lopes, P.R.M., (2010). Microbial biodegradation potential of hydrocarbons evaluated by colorimetric technique: a case study, pp.1277-1288 in Current Research Technology and Education Topics in Applied Microbiology and Microbial Biotechnology, edited by A. Mendez-Vilas. FORMATEX, Spain.

Cain, D., Hanks, H., Weis, M., Bottoms, C. \& Lawson, J., (2013). Microbiology Laboratory Manual, Collin County Community College District, McKinney TX.

Chaillan, F., Fleche, A.L., Bury, E., Phantavong, Y., Grimont, P., Saliot, A. and Oudot, J., (2004). Identification and biodegradation potential of tropical aerobic hydrocarbon-degrading microorganisms. Research in Microbiology, 155, pp.587 - 595. 
Cowan, S.T. \& Steel, K.J.. (1974). Manual for identification of medical bacteria. 2nd ed., Cambridge University Press, Cambridge, England.

Ekhaise, F. O. and Nkwelle, J., (2011). Microbiological and Physicochemical analyses of Oil contaminated Soil from Major Motor Mechanic Workshops in Benin City Metropolis, Edo State, Nigeria Journal Applied Sciences and Environmental Management, 15(4), pp.597 - 600.

Eze, V.C., Onwuakor, C.E. and Orok,, F.E. (2014). Microbiological and Physicochemical Characteristics of Soil Contaminated With Used Petroleum Products in Umuahia, Abia State, Nigeria. Journal of Applied and Environmental Microbiology, 2(6), pp.281 - 286.

Ghazali, F.M., Rahman, R.N.Z.A., Salleh, A.B. and Basri, M., (2004). Biodegradation of hydrocarbons in soil by microbial consortium. International Biodeterioration and Biodegradation, 54, pp.62 - 67.

Hanson, K., Jitendra, G., Desai. D. and Anjana, J.D., (1993). Arapid and screening technique for potential crude oil degrading microorganisms. Biotechnology Techniques, 7(10), pp.745 - 748.

Holt, J.G., Kreig, N.R., Sneath, P.H.A., Stanley, J.T. and William, S.T. (1994). Bergey's manual of Determinative Bacteriology. William and Wikins Baltimore, USA 213pp.

Ijah, J.J. and Abioye, O.P., (2003). Assessment of physicochemical and microbiological properties of soil, 30 months after kerosene spill. Journal of Research and Science Management, 1, pp.24 - 30.

Lloyd, A.C. and Cackette, T.A., (2001). Diesel engines: environmental impact and control. Journal of Air Waste Management Association, 51, pp.809 - 847.

Malik, Z.A. and Ahmed, S., (2011). Degradation of petroleum hydrocarbons by oil field isolated bacterial consortium. African Journal of Biotechnology, 11(3), pp.650 - 658.

Mbachu, A.E., Onochie, C.C., Agu, K.C., Okafor, O.I. and Awah, N.S., (2014). Hydrocarbon degrading potentials of indigenous bacteria isolated from auto-mechanic workshops at Mgbuka-Nkpo, Nigeria. Journal of Global Biosciences, 3(1), pp.321 - 326.

Mills, A., Breuil, L.C. and Colwell, R.R., (1978). Enumeration of petroleum degrading marine and estuarine microorganisms by the most probable number method. Canada Journal of Microbiology, 24, pp.552 - 557.

Nester, E.W., Anderson, D.G., Roberts, C.E., Pearsall, N.N. \& Nester, M.T., (2001) Microbiology: A Human Perspective. 3rd Edition, McGraw-Hill Companies Inc, United States.

Obayori, O.S., Salami, I.B. and Ogunwumi, O.S., (2014). Biodegradation of fresh and used Engine oils by Pseudomonas aeruginosa LP5. Journal of Bioremediation and Biodegradation, 5, pp.213 - 219.

Oboh, B.O., Ilori, M.O., Akinyemi, J.O. and Adebusoye, S.A., (2006). Hydrocarbon Degrading potentials of bacteria isolated from a Nigerian Bitumen (Tarsand) Deposit. Nature Science, 4(3), pp.51 $-57$.

Odjegba, V.J. and Sadiq, A., (2000). Effects of spent Engine oil on the growth parameters, chlorophyll and protein level of Amaranthus hybidus L. Nigerian Journal of Applied Science, 7, pp.1 - 6.

Okerentugba, P.O. and Ezeronye, O.U., (2003). Petroleum degrading potentials of single and mixed microbial cultures isolated from rivers and refinery effluents in Nigeria. African Journal of Biotechnology, 2(9), pp.288 - 292.

Okpokwasili, G.C. and Okorie, B.B., (1988). Biodeterioration potentials of microorganisms isolated from car engine lubricating oil. Tribology International, 21, pp.215-220.

Okoh, A.I., (2006). Biodegradation alternatives in the cleanup of petroleum hydrocarbon pollutants, Biotechnology and Molecular Biology Review, 1(2), pp.38-50.

Onojake, M.C. and Osuji, L.C., (2012). Assessment of the physicochemical properties of hydrocarbon contaminated soil. Archives of Applied Science Research, 4 (1), pp.48 - 58.

Rahman, K.S.M., Rahman, J.T., Lakshmanaperumalsamy, P. and Banat, I.M., (2002). Towards efficient crude oil degradation by a mixed bacterial consortium. Bioresource Technology, 85, pp.257 - 261. 
Sebiomo, A., Awosanya, A.O. and Awofodu, A. D., (2011). Utilisation of crude oil and gasoline by ten bacterial and five fungal isolates Journal of Microbiology and Antimicrobials, 3(3), pp.55 - 63.

Selvakumar, S., Sekar, P., Rajakumar, S. and Ayyasamy,, P.M. (2014). Rapid screening of crude oil degrading bacteria isolated from oil contaminated areas, The Scitech Journal, 1, pp.24 - 27.

Spence, M.J., Bottrell, S.H., Thornton, S.F., Richnow, H.H. and Spencer, K.H., (2005). Hydrochemical and isotopic effects associated with petroleum fuel biodegradation pathways in a chalk aquifer. Journal of Contaminant Hydrology, 79, pp.67 - 88.

Stephen, E., Usman, A.S., Okolo, M.O., Akogu, E.A. and Abioye, O.P., (2013). Microbiological and physicochemical properties of diesel simulated Soil. FUTA Journal of Research in Sciences, 1, pp.82 $-86$. 